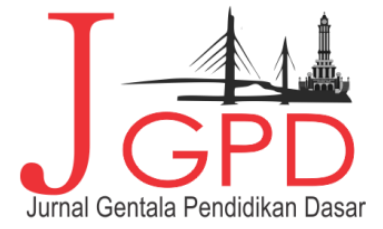

Research Article

\title{
Penerapan Model Pembelajaran The Power Of Two untuk Meningkatkan Hasil Belajar IPS Pada Siswa Kelas IV SDN 104/I Simpang Jebak
}

\author{
Firman Khaidir, Panut Setiono, Muspida Heri
}

Program Studi Pendidikan Guru Sekolah Dasar, FKIP, Universitas Jambi, Jambi, Indonesia

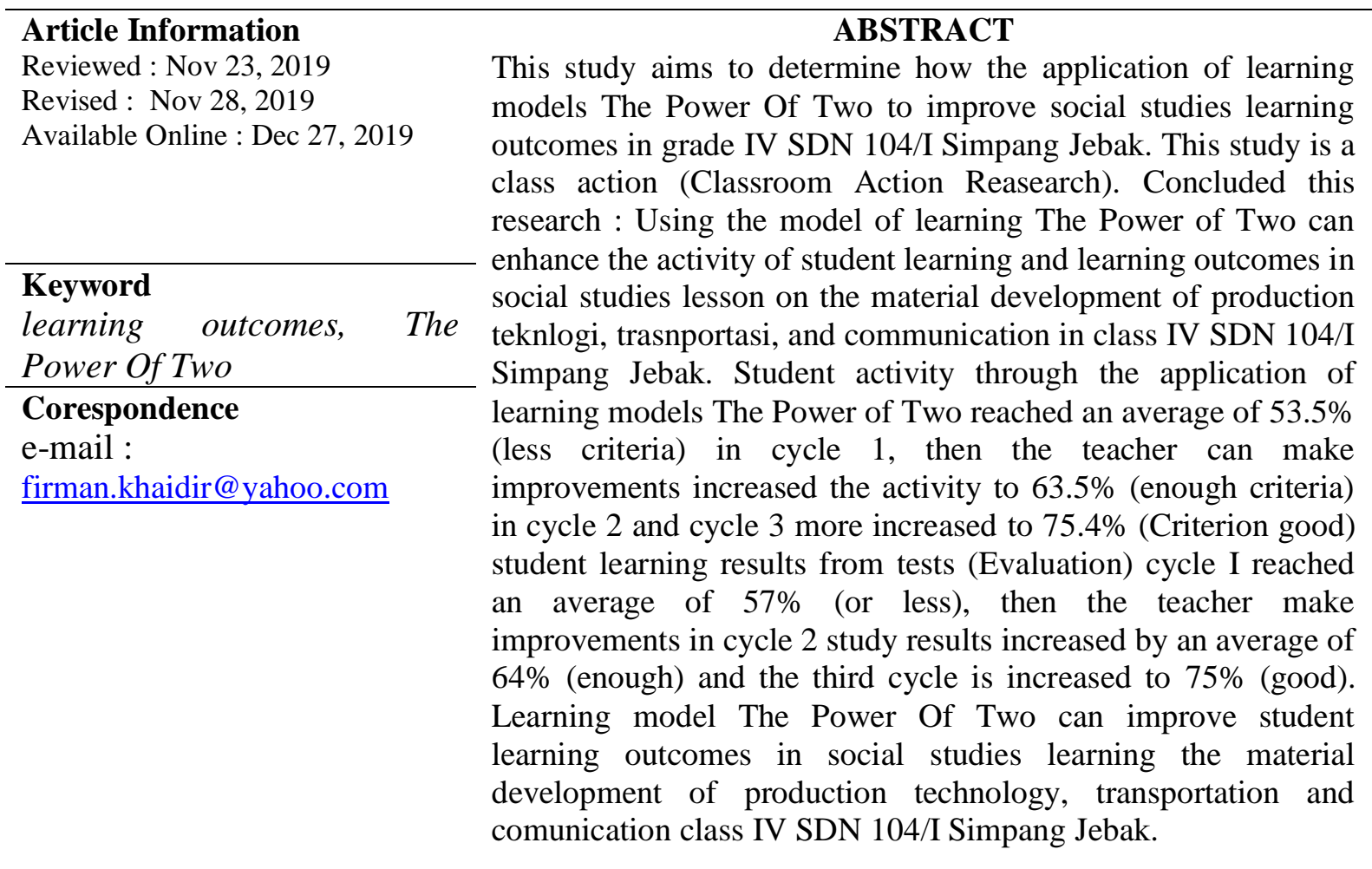

DOI : https://doi.org/10.22437/gentala.v4i2.8451

\section{PENDAHULUAN}

Proses belajar mengajar (PBM) merupakan aktifitas yang penting di dalam pendidikan, karena melalui proses inilah tujuan pembelajaran akan tercapai dalam bentuk perubahan perilaku peserta didik. Menurut Makmum (2006:34) bahwa:

"setidaknya ada 3 unsur yang harus ada dalam proses belajar mengajar, yaitu : (1) peserta didik (siswa/mahasiswa) dengan segala karakteristiknya untuk mengembangkan dirinya seoptimal mungkin melalui kegiatan belajar; (2)pengajar (guru/dosen) yang selalu mengusahakan terciptanya proses belajar sehingga memungkinkan untuk terjadinya proses pengalaman belajar, dan ; (3)tujuan, yaitu sesuatu yang diharapkan setelah adanya kegiatan belajar”. 


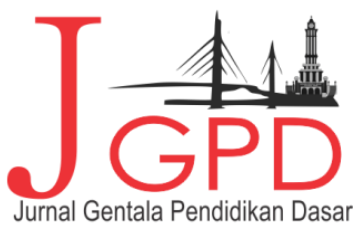

JURNAL GENTALA PENDIDIKAN DASAR Vol. 4 No. 2 December 2019 Page 209-219

P-ISSN : 2614-7092, E-ISSN : 2621-961I

Available Online at Web : http://online-journal.unja.ac.id/index.php/gentala email : penyunting.jurnal.g-pgsd国unja.ac.id

Hamalik (2007:76) juga menambahkan bahwa "belajar bukan suatu tujuan tetapi merupakan suatu proses untuk mencapai tujuan”. Proses pembelajaran yang ditetapkan di sekolah saat ini umumnya merupakan kegiatan belajar yang tidak hanya terpusat pada guru saja (teacher center), tetapi umumnya diterapkan suatu kegiatan pembelajaran yang berpusat pada siswa (student center). Pada kegiatan pembelajaran yang berpusat pada siswa, siswa dituntut untuk lebih aktif dan kreatif, tidak hanya mengharapkan informasi yang diberikan atau disampaikan guru saja.Prinsip yang paling penting dalam pendidikan sekarang adalah guru tidak hanya semata-mata memberikan pengetahuan kepada siswa, tetapi siswa harus bisa membangun sendiri pengetahuan dari dalam dirinya sendiri. Guru disini hanya berperan sebagai fasilitator dan motivator dalam proses belajar siswa.

Berdasarkan informasi dari Ibu Rohimah, S.Pd yang merupakan guru kelas IV SD Negeri No.104/I Simpang Jebak pada tanggal 06 Januari 2016, menyatakan bahwa hasil ulangan harian yang diperoleh siswa pada pembelajaran IPS pada tahun ajaran 2015/2016 masih rendah dengan nilai rata-rata 60. Nilai rata-rata ini masih dibawah Kriteria Ketuntasan Minimum (KKM) yang ditetapkan oleh sekolah yaitu 65. Proses belajar mengajar yang dilakukan lebih cenderung terpusat kepada guru. Lebih lanjut ditambahkan, apabila diberikan soal latihan dan siswa diminta untuk maju menyelesaikannya, siswa yang sering maju hanya siswa-siswa tertentu saja sedangkan siswa yang lain hanya ingin menunggu jawaban dari temannya. Interaksi yang terjadi antara guru dan siswa pun didominasi oleh siswa-siswa tersebut, sehingga tidak semua siswa dapat aktif dalam proses pembelajaran. Padahal belajar hanya mungkin terjadi apabila anak aktif mengalami sendiri (Dimyati dan Mudjiono, 2006:89). Hal ini mengakibatkan suasana kelas membosankan dan kurangnya perhatian untuk mengikuti proses pembelajaran dengan baik.

Agar hasil belajar siswa memuaskan, seorang guru harus mengupayakan agar siswa aktif dalam proses belajar. Guru diharapkan mampu memilih cara mengajar sehingga dapat mengaktifkan siswa. Belajar tidak bisa dipaksakan oleh orang lain dan juga tidak bisa dilimpahkan kepada orang lain. Siswa dapat aktif jika diberikan model pembelajaran yang tepat. Tanpa suatu model yang cocok, tepat, tidak mungkin tujuan dari proses pembelajaran dapat tercapai.

Salah satu alternatif model pembelajaran yang diharapkan dapat mengaktifkan siswa dan mengatasi permasalahan di atas adalah model pembelajaran The Power Of Two. Zaini, dkk (2012:76) menyatakan model ini mempunyai prinsip bahwa berpikir berdua jauh lebih 


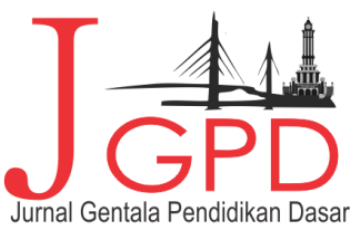

JURNAL GENTALA PENDIDIKAN DASAR Vol. 4 No. 2 December 2019 Page 209-219

P-ISSN : 2614-7092, E-ISSN : 2621-961I

Available Dnline at Web : http://online-juurnal.unja.ac.id/index.php/gentala email : penyunting.jurnal.g-pgsd国unja.ac.id

baik daripada berpikir sendiri. Mafatih (dalam Ramadhan, 2009:56) menambahkan bahwa model pembelajaran The Power Of Two termasuk bagian dari belajar kooperatif adalah belajar dalam kelompok kecil dengan menumbuhkan kerjasama secara maksimal melalui kegiatan pembelajaran teman sendiri dengan anggota dua orang didalamnya untuk mencapai kompetensi dasar. Model pembelajaran The Power Of Two ini terdiri dari dua orang sehingga kerjasama dan komunikasi lebih terjalin dengan baik. Sutrisno dan Dewi (2009:90) menyatakan bahwa model pembelajaran dengan kekuatan dua orang (The Power Of Two strategy), merupakan pembelajaran kooperatif yang di gunakan untuk meningkatkan pembelajaran kolaboratif, menumbuhkan kerjasama secara maksimal, dan memperkuat arti penting manfaat sinergi dua orang.

Model pembelajaran The Power Of Two telah dilaporkan oleh Sutrisno dan Dewi (2009:92), didapatkan bahwa dengan penerapan Model The Power Of Two dapat meningkatkan aktifitas dan Hasil belajar siswa. Kelebihan model The Power Of Two ini antara lain siswa tidak terlalu bergantung kepada guru, serta dapat menambah kepercayaan dan kemampuan berfikir siswa sendiri. Siswa juga dapat belajar untuk mengungkapkan ideide ataupun gagasannya kepada orang lain.

\section{METODE PENELITIAN}

Penelitian ini merupakan penelitian tindakan kelas (Classroom Action Reasearch), dengan ciri utamanya adalah adanya tindakan yang berulang dan metode utamanya adalah refleksi diri yang bertujuan untuk memperbaiki pembelajaran.

Subjek dalam penelitian ini adalah siswa kelas IV SDN No.104/I Simpang Jebak yang berjumlah 19 siswa, dengan rincian 10 laki-laki, 9 perempuan dan Guru Kelas IV yang perjumlah satu orang. Penelitian ini dilaksanakan pada semester genap tahun ajaran 2015/2016, sedangkan objek dalam penelitian ini mencakup pemahaman belajar siswa pada bidang studi IPS Kelas IV.

Penelitian ini dilakukan dalam 3 siklus, setiap siklus terdiri dari 2 kali pertemuan. Pada setiap siklusnya terdiri dari (1) perencanaan, (2) pelaksanaan tindakan, (3) observasi / pengamatan, (4) evaluasi dan (5) refleksi.

Rencana tindakan disusun agar pelaksanaan pembelajaran dengan model The power of two berhasil secara optimal. Pelaksanaan tindakan adalah berupa pembelajaran di kelas. Kegiatan pembelajaran di kelas ini merupakan kegiatan inti dari penelitian tindakan kelas. 


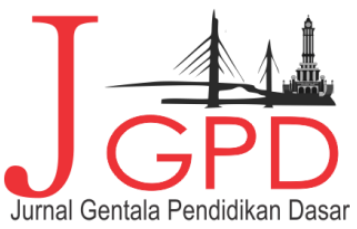

JURNAL GENTALA PENDIDIKAN DASAR Vol. 4 No. 2 December 2019 Page 209-219

P-ISSN : 2614-7092, E-ISSN : 2621-966II

Available Dnline at Web : http://online-juurnal.unja.ac.id/index.php/gentala email : penyunting.jurnal.g-pgsd国unja.ac.id

Tindakan dilaksanakan sebagaimana sesuai dengan rencana pembelajaran yang telah dirancang. Dalam tahap observasi kegiatan observer adalah melakukan observasi terhadap pelaksanaan tindakan guru mengajar di kelas dan aktivitas siswa dalam proses pembelajaran dengan menggunakan lembar observasi yang telah dibuat. Proses observasi dilakukan sejak awal hingga akhir pembelajaran. Kegiatan evaluasi dilakukan dengan memberikan tes tertulis pada akhir siklus dalam bentuk soal pilihan ganda. Kemudian dilakukan pemeriksaan terhadap hasil tes dan dilanjutkan dengan pemberian nilai pada hasil kerja siswa. Di akhir penilaian juga dilakukan penghitungan persentase terhadap ketuntasan belajar siswa, dengan tujuan untuk mengetahui tingkat ketuntasan terhadap materi. Refleksi dilakukan antara peneliti dan guru kolaborasi di mana untuk melakukan refleksi terhadap kegiatan pembelajaran yang dilakukan, Peneliti mengambil data dari kegiatan dan hasil belajar siswa. Kemudian peneliti membandingkan hasil yang diperoleh untuk dijadikan dasar dalam menyusun tindakan pada siklus selanjutnya.

Instrumen yang digunakan dalam penelitian ini adalah tes dan lembar observasi guru dan siswa. Tes yang digunakan dalam penelitian ini berupa tes esai yang memerlukan penalaran yang baik tentang materi yang diajarkan. Tes digunakan untuk mengambil data pada tes tiap siklus. Lembar observasi siswa digunakan untuk mengamati keaktifan siswa selama proses pembelajaran dengan penerapan model The power of two berlangsung.

Data yang didapat berdasarkan hasil observasi maka akan dianalisis untuk mengetahui tingkat keaktifan siswa

Untuk menghitung jumlah siswa yang aktif dalam belajar dengan menggunakan rumus sebagai berikut (Riduwan,2011:41):

$$
\rho=\frac{\sum \mathrm{F}}{\sum \mathrm{N}}=100 \%
$$

Keterangan:

$\mathrm{p} \quad=$ Peresentase

$\Sigma \mathrm{F} \quad=$ Jumlah skor

$\Sigma \mathrm{N} \quad=$ Skor maksimal

Perhitungan persentase setiap indikator keaktifan dapat dihitung dengan menggunakan rumus menurut Purwanto (2009) sebagai berikut: 
$\mathrm{NPNP}=\frac{\mathrm{R}}{\mathrm{SM}} \times 100 \%$

Keterangan :

$\mathrm{NP} \quad=$ Nilai persen yang dicari

$\mathrm{R}=$ Skor mentah yang diperoleh siswa

$\mathrm{SM}=$ Skor maksimum dari indikator keaktifan siswa

Siswa dikatakan aktif didalam pembelajaran apabila sudah mencapai standar ketuntasan yaitu $75 \%$.

Untuk menghitung persentase ketuntasan individu digunakan rumus (Wardhani,2007) Sebagai Berikut:

$K T=\frac{\mathrm{SC}}{\mathrm{SM}} \times 100 \%$

Keterangan :

KT $\quad=$ Persentase ketuntasan belajar

$\mathrm{SC} \quad=$ Jumlah skor yang didapat siswa

$\mathrm{SM}=$ Skor maksimal

Untuk mengetahui sejauh mana penguasaan materi oleh kelas, maka pengolahan hasil penelitian dilakuakan dengan menghitung tes secara keseluruhan dengan menggunakan rumus Riduwan (2011:89), dengan rumus :

Ketuntasan klasikal $=\frac{\text { jumlah siswa } \text { yang tuntas }}{\text { jumlah siswa }} \times 100 \%$

Dan untuk mencari nilai rata-rata hasil tes penilaian proses per siklus, menurut Sudjana(2009), adalah :

$x=\frac{\sum \mathrm{x}}{\mathrm{n}}$

Keterangan :

$\mathrm{X}=$ Rata-rata nilai

$\Sigma \mathrm{x} \quad=$ Jumlah seluruh skor

$\mathrm{n} \quad=$ Jumlah peserta

\section{HASIL PENELITIAN DAN PEMBAHASAN}

Berdasarkan hasil penelitian dari siklus 1 sampai siklus 3 dalam menggunakan model pembelajaran The Power of Two untuk meningkatkan keaktifan hasil belajar siswa dalam pembelajaran IPS pada materi perkembangan teknlogi produksi, trasnportasi, dan komunikasi di kelas IV SD Negeri No.104/I Simpang Jebak. Pada setiap siklusnya terjadi peningkatan keaktifan dan hasil belajar siswa.

Hasil belajar siswa pada pembelajaran IPS pada materi perkembangan teknlogi produksi, trasnportasi, dan komunikasi terbukti adanya peningkatan dengan menggunakan 


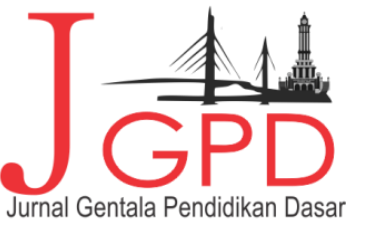

JURNAL GeNTALA PENDIDIKAN DASAR Vol. 4 No. 2 December 2019 Page 209-219 P-ISSN : 2614-7092, E-ISSN : 2621-961I

Available Dnline at Web : http://online-journal.unja.ac.id/index.php/gentala email : penyunting.jurnal.g-pgsd国unja.ac.id

model pembelajaran The Power of Two , karena pada hasil belajar ini merupakan kemampuan-kemampuan yang dimiliki siswa setelah ia menerima pengalaman belajar yang diberikan oleh pengajar ataupun peneliti, disini peneliti berusaha memicu siswa untuk lebih aktif dalam proses pembelajaran sehingga siswa juga mampu untuk menemukan permasalahan dan bagaimana menyelesaikan permasalahan, siswa juga mampu menjawab soal-soal yang telah diberikan oleh peneliti. Dengan hal ini peneliti selalu bertanya tentang hal apa saja yang belum diketahui oleh siswa, dan peneliti membimbing siswa selama proses belajar mengajar berlangsung.

Tabel 1 Distribusi Rekapitulasi Nilai Ketuntasan Hasil Belajar Siswa

\begin{tabular}{|c|c|c|c|c|c|c|c|}
\hline No & $\begin{array}{l}\text { Nama } \\
\text { Siswa }\end{array}$ & $\begin{array}{c}\text { Siklus } \\
\text { I }\end{array}$ & Ketuntasan & $\begin{array}{l}\text { Siklus } \\
\text { II }\end{array}$ & Ketuntasan & $\begin{array}{c}\text { Siklus } \\
\text { III }\end{array}$ & Ketuntasan \\
\hline 1 & $\mathrm{ZA}$ & 50 & Tidak Tuntas & 60 & Tidak Tuntas & 70 & Tuntas \\
\hline 2 & FY & 60 & Tidak Tuntas & 60 & Tidak Tuntas & 70 & Tuntas \\
\hline 3 & $\mathrm{AF}$ & 50 & Tidak Tuntas & 70 & Tuntas & 80 & Tuntas \\
\hline 4 & RK & 50 & Tidak Tuntas & 50 & Tidak Tuntas & 60 & Tidak Tuntas \\
\hline 5 & RA & 60 & Tidak Tuntas & 70 & Tuntas & 80 & Tuntas \\
\hline 6 & RN & 60 & Tidak Tuntas & 60 & Tidak Tuntas & 80 & Tuntas \\
\hline 7 & AM & 60 & Tidak Tuntas & 70 & Tuntas & 70 & Tuntas \\
\hline 8 & AA & 70 & Tuntas & 80 & Tuntas & 90 & Tuntas \\
\hline 9 & DD & 70 & Tuntas & 80 & Tuntas & 80 & Tuntas \\
\hline 10 & FA & 60 & Tidak Tuntas & 70 & Tuntas & 80 & Tuntas \\
\hline 11 & $\mathrm{HZ}$ & 50 & Tidak Tuntas & 70 & Tuntas & 90 & Tuntas \\
\hline 12 & ID & 40 & Tidak Tuntas & 50 & Tidak Tuntas & 60 & Tidak Tuntas \\
\hline 13 & MA & 50 & Tidak Tuntas & 60 & Tidak Tuntas & 90 & Tuntas \\
\hline 14 & NA & 60 & Tidak Tuntas & 70 & Tuntas & 80 & Tuntas \\
\hline 15 & SP & 50 & Tidak Tuntas & 60 & Tidak Tuntas & 80 & Tuntas \\
\hline 16 & SJ & 60 & Tidak Tuntas & 60 & Tidak Tuntas & 70 & Tuntas \\
\hline 17 & TS & 60 & Tidak Tuntas & 60 & Tidak Tuntas & 80 & Tuntas \\
\hline 18 & FM & 70 & Tuntas & 70 & Tuntas & 80 & Tuntas \\
\hline 19 & MA & 70 & Tuntas & 60 & Tidak Tuntas & 70 & Tuntas \\
\hline \multicolumn{2}{|c|}{ \% Rata-rata } & \multicolumn{2}{|r|}{$57 \%$} & \multicolumn{2}{|r|}{$64 \%$} & \multicolumn{2}{|r|}{$75 \%$} \\
\hline \multicolumn{2}{|c|}{ \% Tuntas } & \multicolumn{2}{|c|}{$21,05 \%$} & \multicolumn{2}{|r|}{$47 \%$} & \multicolumn{2}{|r|}{$89 \%$} \\
\hline \multicolumn{2}{|c|}{$\begin{array}{l}\text { \% Tidak } \\
\text { Tuntas }\end{array}$} & \multicolumn{2}{|r|}{$79 \%$} & \multicolumn{2}{|r|}{$54 \%$} & \multicolumn{2}{|r|}{$11 \%$} \\
\hline \multicolumn{2}{|c|}{ Kategori } & \multicolumn{2}{|c|}{ Rendah } & \multicolumn{2}{|c|}{ Kurang } & \multicolumn{2}{|c|}{ Baik } \\
\hline
\end{tabular}

Dari tabel rekapitulasi nilai ketuntasan hasil belajar yang dapat dilihat diatas bahwa terjadi peningkatan yang lebih baik pada nilai ketuntasan siswa pada pembelajaran IPS materi perkembangan teknlogi produksi, trasnportasi, dan komunikasi . Pada siklus I yang dinyatakan tuntas hanya terdiri dari 4 siswa dengan presentase yaitu $21 \%$ dan yang tidak tuntas terdiri dari 15 siswa dengan presentase 79\%, Pada siklus II meningkat hingga siswa yang dinyatakan tuntas terdiri dari 9 siswa dengan presentase $47 \%$ dan siswa yang dinyatakan 


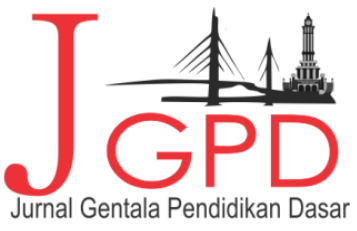

tidak tuntas terdiri dari 10 siswa dengan presentase 54\% dan pada siklus 3 terjadi peningkatan yang sangat baik, sehingga pada siklus 3 siswa yang dikatakan tuntas terdiri 17 siswa dan siswa yang dikatakan tidak tuntas terdiri dari 2 siswa. Hal ini sangat terlihat jelas adanya peningkatan yang semakin membaik pada hasil belajar siswa yang diperoleh setelah menggunakan model pembelajaran The Power of Two pada proses belajar mengajar dikelas. Dapat dilihat hasil perbandingan dari siklus 1 sampai siklus 3 pada gambar 4.1

\section{Gambar 1 Diagram Perbandingan Persentase Ketuntasan Siswa pada Siklus I, II, dan III}

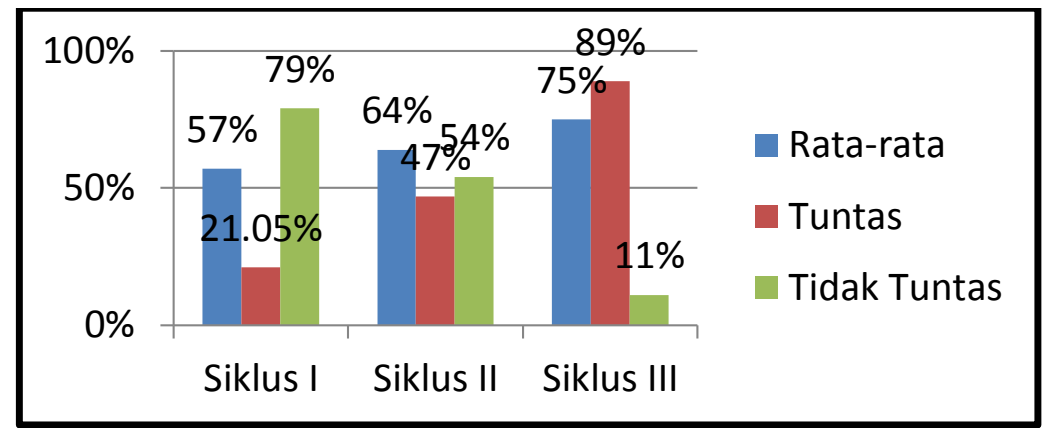

Berdasarkan diagram di atas, persentase siswa yang telah mencapai KKM juga semakin meningkat selama penelitian. Pada siklus 1 ketuntasan siswa baru mencapai 21,05\%, akan tetapi ketuntasan ini belum mencapai kriteria yang ditetapkan yaitu $75 \%$ sehingga dilakukan tindakan siklus 2. Pada tindakan siklus 2 ketuntasan siswa belum memcapai KKM 47\% artinya pada tindakan siklus 2 masih belum mencapai kriteria ketuntasan yang ditetapkan peneliti sehingga penelitian dilanjutkan pada tindakan siklus 3. Pada siklus 3 terjadilah peningkatan yang leih baik, dimana pada siklus 3 ketuntasan hasil belajar siswa mencapai $89 \%$ artinya ketuntasan telah mencapai KKM yaitu 75\%. Sedangkan siswa yang tidak tuntas belajar mengalami penurunan disetiap tahapan penelitian. Pada siklus 1 siswa yang tidak tuntas belajar mencapai 79\%, siklus 2 siswa yang tidak tuntas belajar mencapai $54 \%$ dan pada siklus 3 lebih menurun menjadi $11 \%$.

Kenaikan hasil belajar bisa terjadi dikarenakan semangat siswa dalam kegiatan pembelajaran dengan menggunakan model pembelajaran . Siswa aktif dalam menelaah bahan pelajaran dan bekerja sama serta adanya tanggung jawab dari setiap siswa untuk lebih mampu untuk memahami materi pelajaran dengan menggunakan model pembelajaran The Power of Two. Hal tersebut yang mampu menyebabkan hasil belajar siswa meningkat, meskipun ada beberapa siswa yang hasil belajarnya dinyatakan belum tuntas. 


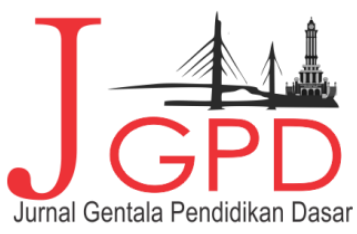

JURNAL GENTALA PENDIDIKAN DASAR Vol. 4 No. 2 December 2019 Page 209-219

P-ISSN : 2614-7092, E-ISSN : 2621-961I

Available Dnline at Web : http://online-juurnal.unja.ac.id/index.php/gentala email : penyunting.jurnal.g-pgsd国unja.ac.id

Dari analisis hasil penelitian ini mulai dari siklus 1 hingga siklus 2, bahwa dengan menerapkan model pembelajaran The Power of Two pada pembelajaran IPS materi perkembangan teknlogi produksi, trasnportasi, dan komunikasi di kelas IV SD Negeri No.104/I Simpang Jebak dapat mengatasi masalah dan kendala dalam belajar, guru harus tetap mengawasi siswa dan membentuk kelompok belajar secara heterogen serta pendekatan dan penggunaan model-model pembelajaran dalam proses belajar mengajar, sehingga hal tersebut dapat meningkatkan keaktifan dan hasil belajar siswa. Berdasarkan hasil pengamatan siklus 3 ini , maka tindakan dapat dihentikan karena baik keaktifan siswa dan hasil belajar siswa telah mencapai target yang di tetapkan. Berdasarkan hasil observasi keaktifan siswa dan hasil belajar yang meningkatkan pada siklus 1 sampai siklus 2, maka dapat disimpulkan bahwa penelitian ini berhasil pada siklus ke 3 .

Berdasarkan penelitian yang telah dilakukan yaitu melalui kegiatan Penelitian Tindakan Kelas (PTK) menggunakan pendekatan kooperatif dengan menggunakan model The Power Of Two. Setelah dilakukan penelitian dalam meningkatkan hasil belajar siswa pada model pembelajaran The Power of Two dalam pembelajaran IPS dengan materi perkembangan teknologi produksi, transportasi, dan komunikasi dikelas IV SD Negeri No.104/I Simpang Jebak dapat disimpulkan bahwa dengan menggunakan model pembelajaran The Power Of Two dapat meningkatkan hasil belajar dalam pembelajaran IPS dengan materi perkembangan teknologi produksi, transportasi, dan komunikasi dikelas IV SD Negeri No.104/I Simpang Jebak. Hasil belajar siswa dari tes (Evaluasi) siklus I mencapai rata-rata sebesar 57\% (kurang), kemudian peneliti melakukan perbaikan pada siklus II sehingga hasil belajar meningkat dengan rata-rata $64 \%$ (cukup) dan pada siklus III lebih meningkat lagi menjadi 75\% (baik).

Hasil penelitian tersebut sesuai dengan teori yang dikemukakan oleh Djamarah (2006:16-18) bahwa dalam model pembelajaran The Power Of Two siswa tidak terlalu bergantung pada guru, akan tetapi dapat menambah kepercayaan kemampuan berfikir sendiri, menemukan informasi dari berbagai sumber dan belajar dari siswa lain, mengembangkan kemampuan, mengungkap idea tau gagasan dengan kata-kata secara verbal dan dengan membandingkan ide-ide atau gagasan orang lain, membantu anak agar dapat bekerja sama dengan orang lain, dan menyadari segala keterbatasanya, membantu siswa untuk lebih bertanggung jawab dalam melaksanakan tugasnya, meningkatkan motivasi dan 


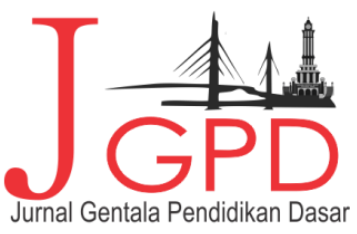

JURNAL GENTALA PENDIDIKAN DASAR Vol. 4 No. 2 December 2019 Page 209-219

P-ISSN : 2614-7092, E-ISSN : 2621-961I

Available Dnline at Web : http://online-juurnal.unja.ac.id/index.php/gentala email : penyunting.jurnal.g-pgsd国unja.ac.id

memberikan rangsangan untuk berfikir, meningkatkan prestasi akademik sekaligus kemampuan sosial.

Secara keseluruhan model pembelajaran The Power Of Two menciptakan suasana pembelajaran yang efekti, siswa terlibat lebih aktif dan lebih mandiri, siswa berusaha bersama teman kelompok untuk memecahkan masalah masalah bersama-sama. Dari hasil penelitian ini dimulai dari siklus 1 hingga siklus 3, bahwa dengan penerapan model pembelajaran The Power of Two dalam pembelajaran IPS dengan materi perkembangan teknologi produksi, transportasi, dan komunikasi dikelas IV SD Negeri No.104/I Simpang Jebak dapat mengatasi masalah dan kendala dalam belajar, peneliti tetap mengawasi siswa dalam membentuk kelompok belajar secara heterogen serta pendekatan dan penggunaan model-model pembelajaran dalam proses belajar mengajar, sehingga hal tersebut dapat meningkatkan keaktifan dan hasil belajar siswa berdasarkan pengamatan siklus 3 ini, maka tindakan dapat dihentikan karena baik keaktifan siswa dan hasil belajar siswa telah mencapai target yang ditetapkan. Berdasrkan hasil belajar yang meningkat pada siklus 1 sampai siklus 3. Dengan demikian hipotesis dalam penelitian The Power Of Two dapat meningkatkan hasil belajar siswa pada pembelajaran IPS dengan materi perkembangan teknologi produksi, transportasi, dan komunikasi dikelas IV SD Negeri No.104/I Simpang Jebak terjawab, dimana dengan menggunakan model pembelajaran ini dapat meningkatkan hasil belajar siswa.

\section{KESIMPULAN DAN IMPLIKASI}

\section{Kesimpulan}

Setelah dilakukan penelitian mengenai Meningkatkan Hasil Belajar siswa pada Model pembelajaran The Power of Two dalam Pembelajaran IPS dalam Materi Perkembangan teknlogi produksi, trasnportasi, dan komunikasi di Kelas IV di SD Negeri No.104/I Simpang Jebak dapat disimpulkan bahwa:

Dengan menggunakan model pembelajaran The Power of Two dapat meningkatkan keaktifan belajar siswa dan hasil belajar dalam pembelajaran IPS pada materi perkembangan teknlogi produksi, trasnportasi, dan komunikasi di kelas IV SD Negeri No.104/I Simpang Jebak. Keaktifan siswa melalui penerapan model pembelajaran The Power of Two mencapai rata-rata 53,5\% (kriteria kurang) pada siklus 1, kemudian dengan guru melakukan perbaikan dapat meningkat keaktifan menjadi 63,5\% (kriteria cukup) pada siklus 2 dan pada siklus 3 


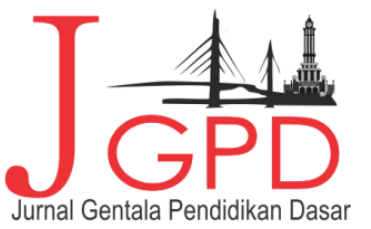

JURNAL GENTALA PENDIDIKAN DASAR Vol. 4 No. 2 December 2019 Page 209-219

P-ISSN : 2614-7092, E-ISSN : 2621-961I

Available Cnline at Web : http://online-journal.unja.ac.id/index.php/gentala email : penyunting.jurnal.g-pgsd国unja.ac.id

lebih meningkat menjadi 75,4\% ( Kriteria baik)Hasil belajar siswa dari tes (Evaluasi) siklus I mencapai rata-rata sebesar 57\%(kurang), kemudian guru melakukan perbaikan pada siklus 2 sehingga hasil belajar meningkat dengan rata-rata 64\%(cukup) dan pada siklus 3 lebih meningkat menjadi 75\% (baik).

\section{Implikasi}

Keberhasilan penerapan model pembelajaran The Power of Two sebagai salah satu upaya untuk meningkatkan keaktifan dan hasil belajar IPS pada materi perkembangan teknlogi produksi, trasnportasi, dan komunikasi di kelas IV SD Negeri No.104/I Simpang Jebak dapat digunakan menjadi dasar bagi peneliti untuk memberikan saran-saran sebagai berikut: (1) Bagi guru : Guru dapat menerapkan model pembelajaran The Power of Two sebagai metode pembelajaran dalam menyampaikan materi mata pelajaran IPS yang membutuhkan pemahaman yang baik untuk siswa kelas IV SD Negeri No.104/I Simpang Jebak. (2) Bagi Kepala sekolah : Melakukan pembinaan kepada guru untuk menggunakan model yang variatif misalnya model Snowball Throwing, sehingga akan menciptakan pembelajaran aktif dan menyenangakan guna mencapai tujuan pembelajaran secara maksimal.

\section{DAFTAR PUSTAKA}

Arikunto, S. 2010. Prosedur Penelitian Suatu Pendekatan Praktik. Jakarta: Rineka Cipta. Arikunto,S. 2006. Prosedur Penelitian suatu Pendekatan Praktik. Jakarta : Rineka Cipta Asmani. 2011. 7 Tips Aplikasi PAKEM (Pembelajaran Aktif, Kreatif, Efektif dan Menyenangkan). Jogjakarta: Diva Press

Asrosi, M. 2010. Psikologi Remaja: Perkembangan Peserta Didik. Jakarta: Media Grafika Ekawarna. 2009. Penelitian Tindakan Kelas. Jakarta: Gaung Persada Press

Dimyanti dan Mudjiono. 2006. Belajar dan Pembelajaran. Jakarta: PT. Rineka Cipta Gunawan, R. 2011. Pendidikan IPS Filosofi, Konsep, dan Aplikasi. Bandung: Alfabeta Hamalik, O. 2005. Kurikulu dan Pembelajaran. Jakarta: Bumi Aksara

Hisbullah, 2011. Penerapan Model PembelajaranSnowball Throwing Dalam Meningkatkan Hasil Belajar IPA di Kelas V SD Negeri 08 Lumaring Kecamatan Larompong Kabupaten Luwu.Skripsi. Makassar: Fakultas Ilmu Pendidikan Universitas Negeri Makassar

Isjoni. 2007. Cooperative Learning Efektifitas Pembelajaran Kelompok. Pekanbaru : Alfabeta Komalasari, K. 2011. Pembelajaran Kontekstual Konsep dan Aplikasi. Bandung: PT Refika Aditama

Kunandar. 2008. Langkah Mudah Penelitian Tindakan Kelas Sebagai Pengembangan Profesi Guru. Jakarta : Raja Grafindo Persada 
Kurniawan, A. R., Noviyanti, S., \& Arsil, A. (2019). Optimasi Model Problem Based Learning Berbantuan Multimedia untuk Meningkatkan Keterampilan Kerja Tim di Sekolah Dasar. ELSE (Elementary School Education Journal): Jurnal Pendidikan dan Pembelajaran Sekolah Dasar, 3(2), 7-16.

Purwanto, N. 2006. Psikologi Pendidikan. Bandung: PT. Remaja Rosdakarya

Purwanto. 2009. Evaluasi Hasil Belajar. Surakarta: Pustaka Belajar

Purwanto. 2013. Evaluasi Hasil Belajar. Yogyakarta: Pustaka Pelajar

Riduwan. 2011. Dasar-dasar Statistika. Bandung: Alfabeta

Sapriya. 2009. Pendidikan IPS Konsep dan Pembelajaran. Bandung: PT. Rosdakarya

Sudjana, N. 2009. Penelitian Hasil Proses Belajar Mengajar. Bandung: Rosdakarya

Sudjana. 2010. Strategi Belajar Mengajar. Jakarta: Rineka Cipta

Suprijono, A. 2011. Cooperative Learning. Yogyakarta: Pustaka Pelajar

Suprijono, A. 2012. Metode dan Model-model Mengajar. Bandung: Alfabeta

Susanto, A. 2013. Teori Belajar dan Pembelajaran di Sekolah Dasar. Jakarta: Kencana Prenada Media Group

Wardhani. 2007. Hubungan Praktek Kebersihan Diri dan Penggunaan Alat Pelindung Diri Dengan Kejadian Skabies Pada Pemulung di TPA Bukung Bandar Lampung. Skripsi.Semarang.UNDIP 